$\begin{array}{lll}\text { Volume : } 1 & \text { No : } 2 \text { November } 2016 & \text { ISSN : } 2502-7069\end{array}$

\title{
PENGARUH KUALITAS KEHIDUPAN KERJA DAN KINERJA GURU TERHADAP KEPUASAN KERJA GURU SMA NEGERI DI KOTA MATARAM
}

\author{
Oleh : \\ Hamidi1, A. Wahab Jufri2, Wayan Karta3 \\ Program Studi Magister Administrasi Pendidikan123 \\ Program Pascasarjana Universitas Mataram123 \\ Email: hamidi@unram.ac.id
}

\begin{abstract}
Abstrak : Tujuan penelitian ini adalah untuk mengetahui pengaruh kualitas kehidupan kerja dan kinerja guru terhadap kepuasan kerja guru SMA Negeri di Kota Mataram. Penelitian ini merupakan penelitian kuantitatif dengan metode ex-post facto. Populasi penelitian ini adalah seluruh guru SMA Negeri di Kota Mataram yang berjumlah 580. Sampel penelitian berjumlah 85 guru yang diambil dengan teknik proportionate random sampling. Hasil penelitian adalah: 1) terdapat pengaruh kualitas kehidupan kerja sebesar $9,2 \%$ terhadap terhadap kepuasan kerja guru SMA Negeri di Kota Mataram, 2) terdapat pengaruh kinerja guru sebesar 9,5\% terhadap kepuasan kerja guru SMA Negeri di Kota Mataram, 3) terdapat pengaruh kualitas kehidupan kerja dan kinerja guru secara bersama-sama sebesar 17,7\% terhadap kepuasan kerja guru SMA Negeri di Kota Mataram. Dengan demikian, dapat disimpulkan bahwa semakin baik kualitas kehidupan kerja dan kinerja guru, kepuasan kerja guru SMA Negeri di Kota Mataram akan semakin meningkat.
\end{abstract}

Kata Kunci: Kualitas Kehidupan Kerja, Kinerja Guru, dan Kepuasan Kerja Guru

Abstract : The aims of this study is to know the effect of quality of work life and teacher performance to teacher job satisfaction at senior high schools in Mataram. This research is a quantitative method of ex-post facto. The population of this research is all teacher of senior high school in Mataram amounting to 580. The sample are 85 teachers taken with proportionate random sampling technique. The results of the research are: 1) there are significant effect of quality of working life amounted to 9,2\% to teachers job satisfaction at senior high school in Mataram City, 2) there are significant effect of teacher performance amounted to $9.5 \%$ to teachers job satisfaction at senior high school in Mataram City, 3) there are significant effect of quality of work life and together with teachers performance amounted to 17,7\% to teachers job satisfaction at senior high school in Mataram City. Therefore, it can be concluded that the better quality of work life and teachers performance, teacher job satisfaction at senior high school in Mataram City will be increase.

Keywords: Quality of Work Life, Teachers Performance, and Teacher Job Satisfaction. 


\section{PENDAHULUAN}

Penting bagi sekolah untuk membuat guru merasa nyaman dengan pekerjaan dan lingkungan kerja sehingga mereka mendapatkan kepuasan dalam bekerja. Banyak hal yang perlu diperhatikan untuk mencapai kepuasan kerja guru, salah satunya adalah memperhatikan kualitas kehidupan kerja (quality of work life) yang merupakan persepsi guru terhadap kesejahteraan fisik dan psikologis mereka di sekolah. Kualitas kehidupan kerja mencakup pemberian kesempatan pada guru untuk mengambil keputusan yang terkait dengan pekerjaannya, desain tempat kerjanya, serta kebutuhan guru untuk lebih berkreasi. Kualitas kehidupan kerja membicarakan sejauh mana guru merasa bahwa dirinya aman, sejahtera, dan mampu mengembangkan diri (Botutihe, 2010:241).

Setiap organisasi termasuk sekolah memiliki permasalahan yang harus dihadapi. Kepuasan kerja guru adalah salah satu hal yang penting untuk diperhatikan dan ditingkatkan. Untuk meningkatkan kepuasan kerja guru di sekolah, salah satu yang bisa diupayakan adalah meningkatkan kualitas kehidupan kerja (quality of work life). Hasil penelitian yang dilakukan oleh Jofreh (2012:2513) menyimpulkan bahwa, kualitas kehidupan kerja berpengaruh positif terhadap kepuasan kerja karyawan dalam organisasi. Kasraie (2014: 80), Kermansaravi (2015:231) menyimpulkan bahwa, there is positif and significant relationship between quality of work life and job satisfaction. Dari hasil penelitian tersebut menunjukkan bahwa, dengan kualitas kehidupan kerja yang tinggi, maka tingkat kepuasan kerja guru dalam bekerja akan semakin meningkat dan sebaliknya dengan kualitas kehidupan kerja yang rendah, kepuasan kerja guru juga akan rendah.

Kualitas kehidupan kerja (Quality of work life) merupakan gambaran kualitas hubungan personal dengan kondisi kerja secara keseluruhan. Rokhman (2012:1135) mengemukakan bahwa penciptaan lingkungan kerja yang berkualitas merupakan tugas seluruh komponen yang ada di organisasi. Kualitas kehidupan kerja merupakan konsep yang multidimensial yang meliputi berbagai aspek yang ada dalam kerja yang berdampak pada kinerja organisasi secara keseluruhan.

Berdasarkan pemaparan diatas, kualitas kehidupan kerja (Quality of work life) merupakan masalah yang harus mendapatkan perhatian penuh dalam suatu organisasi (sekolah). Dengan parhatian yang penuh di sekolah, kualitas kehidupan kerja akan mampu meningkatkan peran serta tugas guru sebagai tenaga pendidik. Sebagai tenaga pendidik yang baik, guru harus mampu memberikan peran terbaik agar tujuan pendidikan bisa tercapai. Dengan kualitas kehidupan kerja yang baik, diharapkan kinerja guru akan semakin baik karena tujuan dasar dari kualitas kehidupan kerja adalah untuk mengembangkan lingkungan kerja sebaik mungkin bagi semua anggota dalam suatu organisasi sehingga mampu memberikan kepuasan kerja yang tentunya berdampak positif terhadap kinerja karyawan.

Menurut Cascio (2003), usaha organisasi untuk memperbaiki kualitas kehidupan kerja (qulity of work life) adalah usaha untuk memperbaiki komponen berikut: 1) Keterlibatan karyawan (Employee participation). (2) Pengembangan karir (Career development). (3) Rasa bangga terhadap institusi (Pride). (4) Kompensasi yang seimbang (Equitable compensation). (5) Rasa aman terhadap pekerjaan (Job 
security). (6) Fasilitas yang didapat (Wellness). (7) Keselamatan lingkungan kerja (Save environment). (8) Penyelesaian masalah (Conflict resolution). (9) Komunikasi (Communication).

Selain kualitas kehidupan kerja, kepuasan kerja seseorang juga dapat dipengaruhi oleh kinerjanya. Seseorang akan merasa puas apabila pekerjaan yang dilakukannya dapat dilakukan dengan baik. Sama halnya dengan seorang guru, akan merasa puas apabila pekerjaannya dalam mengajar dilakukan dengan sebaik-baiknya. Kepuasan kerja guru dapat dipandang sebagai pernyataan positif hasil dari penilaian guru terhadap apa yang telah dilakukan oleh sekolah kepada guru-guru. Kepuasan kerja guru dipercaya akan dapat menumbuhkan motivasi guru untuk tetap tinggal sebagai pengajar yang baik dalam sekolah tersebut.

Kinerja guru yang rendah akan mempengaruhi kepuasan kerja guru di sekolah karena kepuasan kerja merupakan suatu kondisi emosional yang menyenangkan atau tidak menyenangkan dalam persepsi seseorang dalam kondisi kerja. Kepuasan kerja guru ditunjukkan melalui sikap umum terhadap pekerjaan yang dilakukan oleh seorang guru di sekolah. Rokman (2012:1138) menyatakan bahwa salah satu faktor yang mempengaruhi kepuasan kerja adalah sikap yang ditunjukkan seseorang tehadap pekerjaannya yang menyenangkan atau tidak menyenangkan.

Seseorang akan merasa puas apabila mampu menyelesaikan pekerjaannya dengan baik, terlebih lagi mendapatkan sanjungan atas pekerjaan yang dilakukannya. Jadi, dengan kinerja guru yang baik akan mempengaruhi tingkat kepuasan kerjanya sebagai guru di sekolah. Herzberg (dalam Perdani, 2010) menyatakan bahwa, kepuasan seseorang dapat dilihat dari prestasi kerjanya. Prestasi kerja dalam hal ini adalah kesuksesan dalam menyelesaikan pekerjaan, mengatasi masalah, dan usaha bertahan pada satu pekerjaan.

$$
\text { Yuliejantiningsih }
$$

mengemukakan bahwa kinerja adalah perwujudan kemampuan dan keterampilan intelektual serta sifat-sifat pribadi dalam bentuk perilaku atau kegiatan yang dilakukan untuk mencapai suatu hasil kerja tertentu. Dalam suatu organisasi hasil kerja yang dicapai individu mengacu pada tujuan organisasi. Menurut Mangkunegara (2006:67) kinerja adalah kerja secara kualitas dan kuantitas yang dicapai oleh seorang pegawai dalam melaksanakan tugasnya sesuai dengan tanggung jawab yang diberikan kepadanya. Pengertian lain mengenai kinerja diungkapkan oleh Rivai (2008:14) adalah tingkat hasil keberhasilan seseorang secara keseluruhan selama periode tertentu di dalam melaksanakan tugas dibandingkan dengan berbagai kemungkinan, seperti standar hasil kerja, target atau sasaran atau kreteria yang telah ditentukan terlebih dahulu dan telah disepakati bersama. Supardi (2014:54) menyatakan bahwa kinerja guru merupakan kemampuan seorang guru melaksanakan tugas pembelajaran di sekolah dan bertanggung jawab atas peserta didik di bawah bimbingannya dengan meningkatkan prestasi belajar peserta didik. Oleh karena itu, kinerja guru itu dapat dikatakan sebagai suatu kondisi yang menunjukkan kemampuan seorang guru dalam menjalankan tugasnya di sekolah serta menggambarkan suatu perbuatan yang ditampilkan guru selama melakukan aktivitas pembelajaran.

Berdasarkan pemaparan di atas, dapat disimpulkan bahwa kinerja adalah hasil kerja atau prestasi yang dicapai oleh seseorang, yang dinilai berdasarkan kualitas dan kuantitasnya, 
sesuai dengan tugas dan tanggung jawab yang dibebankan kepadanya dalam rangka mencapai tujuan bersama. Dengan demikian, kinerja guru adalah hasil yang dicapai oleh guru dalam melaksanakan tugas-tugas dalam pembelajaran yang dibebankan kepadanya yang dilihat melalui kegiatan perencanaan pembelajaran, pelaksanaan pembelajaran, pelaksanaan penilaian pembelajaran, dan tindak lanjut hasil penilaian.

Supardi (2014: 73) bahwa indikator penilaian kinerja guru adalah: (1) kemampuan menyusun rencana pembelajaran, (2) kemampuan melaksanakan pembelajaran, (3) kemampuan mengadakan hubungan antar pribadi, (4) kemampuan melaksanakan penilaian hasil belajar, (5) kemampuan melaksanakan pengayaan, dan (6) kemampuan melaksanakan remedial. Penelitian ini menggunakan toeri Supardi sebagai indikator dalam menentukan kinerja guru SMAN di Kota Mataram.

Kepuasan kerja guru erat kaitannya dengan kompetensi guru. Hasil Uji Kompetensi Guru (UKG) 2015 menunjukkan bahwa, hanya $10 \%$ guru yang mendapat skor nilai di atas 5,5. Menurut Kepala Lembaga Penjamin Mutu Pendidikan (LPMP) Provinsi NTB, masih ada $90 \%$ guru di NTB yang kompetensinya sangat perlu mendapat perhatian untuk ditingkatkan. Jika mengacu pada hasil skor nilai UKG tahun 2014, sebagian besar guru di NTB mendapatkan nilai di bawah 4,7. Hal ini menunjukkan bahwa, guru di Provinsi NTB memiliki kompetensi dan profesionalisme masih dalam kategori rendah. Meskipun ada peningkatan, tetapi nilai UKG pada tahun 2015 tersebut masih kurang membanggakan (Sudirman, 2015:1).

Data kompetensi guru yang masih rendah di atas menyimpulkan bahwa, kepuasan kerja guru di NTB termasuk guru SMA Negeri di Kota Mataram juga masih dalam kategori rendah. Dengan kompetensi guru yang baik, maka kepuasan kerja guru SMA Negeri di Kota Mataram akan semakin baik. Hasil penelitian Amir (2014:104), Tasir (2012: 143), Singh (2013:183), dan Marsana (2010:13) menyimpulkan bahwa, kompetensi guru yang baik diikuti dengan meningkatnya kepuasan kerja guru.

Susilowati(2009:3)menyatakan bahwa kepuasan kerja pada dasarnya merupakan hal yang bersifat individual, setiap individu akan memiliki tingkat kepuasan yang berbedabeda dengan sistem nilai yang berlaku pada dirinya. Sedangkan Amstrong (2006:264) mengemukakan bahwa kepuasan kerja (job satisfaction) mengacu pada sikap dan perasaan yang dimiliki seseorang mengenai pekerjaan. Dari beberapa pengertian kepuasan kerja yang dikemukakan di atas menunjukkan bahwa kepuasan kerja berhubungan dengan perasaan seseorang yang menyenangkan dan menyenangkan. Oleh karena perasaan tersebut dirasakan oleh seseorang sebagai individu maka kepuasan kerja seseorang bisa berbeda dengan orang lain.

Menurut Herzberg seperti dikemukakan Robbins (2001:170), faktorfaktor yang menghantar kepada kepuasan kerja terpisah dan berbeda dari faktorfaktor yang menghantarkepada ketidakpuasan kerja. Lebih lanjut Herzberg mengemukakan bahwa lawan dari "kepuasan" bukanlah "ketidakpuasan" seperti yang diyakini orang secara tradisional. Namun, Herzberg menyatakan bahwa lawan "kepuasan" adalah "tidak ada kepuasan" dan lawan "ketidakpuasan" adalah "tidak ada ketidakpuasan". Penelitian ini memilih teori dua faktor sebagai acuan untuk mengetahui kepuasan kerja guru karena penelitian ini 
hanya akan mengetahui kepuasan kerja dari faktor intrinsik (Motivator Factor) tanpa melihat pada harapan dan kenyataan yang terjadi atau keadilan yang dirasakan.

Faktor motivator mencakup faktorfaktor yang berhubungan dengan isi dari pekerjaan yang merupakan faktor intrinsik yang meliputi faktor prestasi (achievement), faktor pengakuan (recognition), faktor pekerjaan itu sendiri (the work it self), faktor tanggung jawab (responsible), faktor kemajuan (advancement), dan faktor pertumbuhan (possibility of growth) (Elfitrie, 2006). Faktor hygiene mencakup faktor-faktor yang berkaitan dengan ekstrinsik pekerjaan yang meliputi kebijakan dan administrasi perusahaan/organisasi, supervisi, hubungan antarpribadi (atasan, bawahan, dan rekan kerja), kondisi kerja, gaji, status, dan keamanan kerja.

Berdasarkan kajian teori yang telah dikemukakan, maka dapat dirumuskan hipotesis penelitian sebagai berikut:

1. $\mathrm{H} 0=$ Terdapat pengaruh kualitas kehidupan kerja terhadap kepuasan kerja guru SMA Negeri di Kota Mataram.

2. $\mathrm{HO}=$ Terdapat pengaruh kinerja guru terhadap kepuasan kerja guru SMA Negeri di Kota Mataram.

3. $\mathrm{HO}=$ Terdapat pengaruh kualitas kehidupan kerja dan kinerja guru terhadap kepuasan kerja SMAN di Kota Mataram secara bersama.

\section{METODE PENELITIAN}

Penelitian ini akan dilaksanakan di SMAN yang ada di Kota Mataram Provinsi Nusa Tenggara Barat. Penelitian ini menggunakan pendekatan ex-post facto artinya peneliti tidak menggunakan perlakuan terhadap variabel-variabel penelitian, melainkan mengkaji fakta-fakta yang telah terjadi. Populasi dalam penelitian ini adalah kualitas kehidupan kerja, kinerja guru dan kepuasan kerja SMAN di Kota Mataram yang berjumlah 580 orang. Sampel penelitian sebanyak 85 orang atau $14,65 \%$ dari populasi penelitian.

Instrumen penelitian yang dipakai sebagai alat ukur variabel penelitian adalah angket model skala Likert dengan 5 (lima) pilihan jawaban. Sugiyono (2008) mengatakan bahwa skala tersebut dapat digunakan untuk mengukur sikap, pendapat dan persepsi seseorang atau sekelompok orang tentang fenomena tertentu. Pemilihan instrumen kuesioner (angket) model skala Likert berdasarkan pada pertimbangan bahwa dengan instrumen ini jawaban responden dapat diperoleh secara memadai dan memudahkan dalam pengolahan/mendeskripsikan hasilnya serta sesuai dengan tujuan yang hendak dicapai dalam penelitian ini.

Instrumen yang baik dalam penelitian adalah instrumen yang valid dan reliabel. Uji validitas instrumen dilakukan melalui 2 tahapan yaitu validitas konstruk dan validitas butir. Sukardi (2008: 32) menyatakan bahwa validitas kontruk ditentukan atas dasar pertimbangan (judgment) dari para ahli. Setidaknya, para ahli yang melakukan validasi konstruk dan isi sebanyak 3 orang. Menurut Sugiyono (2011:348) validitas adalah suatu ukuran yang menunjukkan tingkat-tingkat kevalidan atau kesahihan suatu instrumen.

Cara untuk mengukur validitas butir soal yaitu menggunakan rumus korelasi product moment dengan angka kasar,

$$
r_{x y}=\frac{N \sum X Y-\left(\sum X\right)\left(\sum Y\right)}{\sqrt{\left\{N \sum X^{2}-\left(\sum X\right)^{2}\right\}\left\{N \sum Y^{2}-\left(\sum Y\right)^{2}\right\}}}
$$


Setelah harga koefisien validitas tiap butir soal diperoleh, perlu dilakukan uji signifikansi untuk mengukur keberartian koefisien korelasi berdasarkan distribusi kurva normal dengan menggunakan statistik uji-t dengan persamaan:

$$
t=r_{x y} \sqrt{\frac{N-2}{1-r_{x y} 2^{\square}}}
$$

Untuk mengetahui reliabilitas seluruh tes digunakan rumus Alfa Cronbach sebagai berikut:

$$
r_{11=\left(\frac{n}{n-1}\right)}\left(1-\frac{\sum \sigma_{1}^{2}}{\sigma_{1}^{2}}\right.
$$

Perhitungan validitas dan reliabilitas instrumen dengan persamaan di atas menggunakan program SPSS versi 17.0 for Windows.

Teknik analisis data yang dipergunakan dalam penelitian ini adalah analisis regresi, baik regresi sederhana maupun regresi ganda. Langkah berikutnya adalah melaksanakan uji persyaratan analisis data yang meliputi uji multikolinieritas, otokorelasi, homogenitas, dan normalitas data dan dilanjutkan dengan pengujian hipotesis.

Pengaruh secara kuantitatif antara variabel bebas $\mathrm{X}$ terhadap variabel terikat $\mathrm{Y}$ dihitung dengan menganalisis bentuk

persamaan regresi linier sederhana, dengan model persamaan:

$y=a+b X+\varepsilon$

Keterangan:

a $\quad=$ konstanta regresi

b = Koefisien regresi

$\mathrm{Xi} \quad=$ Variabel bebas

$\varepsilon \quad=$ Kesalahan prediksi

Untuk mengetahui seberapa besar pengaruh kualitas kehidupan kerja dan kinerja guru secara bersama-sama terhadap kepuasan kerja guru, maka dihitung juga dengan menganalisis bentuk regresi ganda dengan persamaan:

$y=a+b 1 X 1+b 2 X 2+\varepsilon$

Keterangan:

a $\quad=$ konstanta regresi

$\mathrm{b} 1, \mathrm{~b} 2=$ Koefisien regresi

$\mathrm{X} 1, \mathrm{X} 2=$ Variabel Bebas

$\varepsilon \quad=$ Kesalahan prediksi

\section{HASIL DAN PEMBAHASAN}

Berdasarkan analisis desfriptif, diperoleh data seperti yang ditunjukkan pada Gambar berikut.

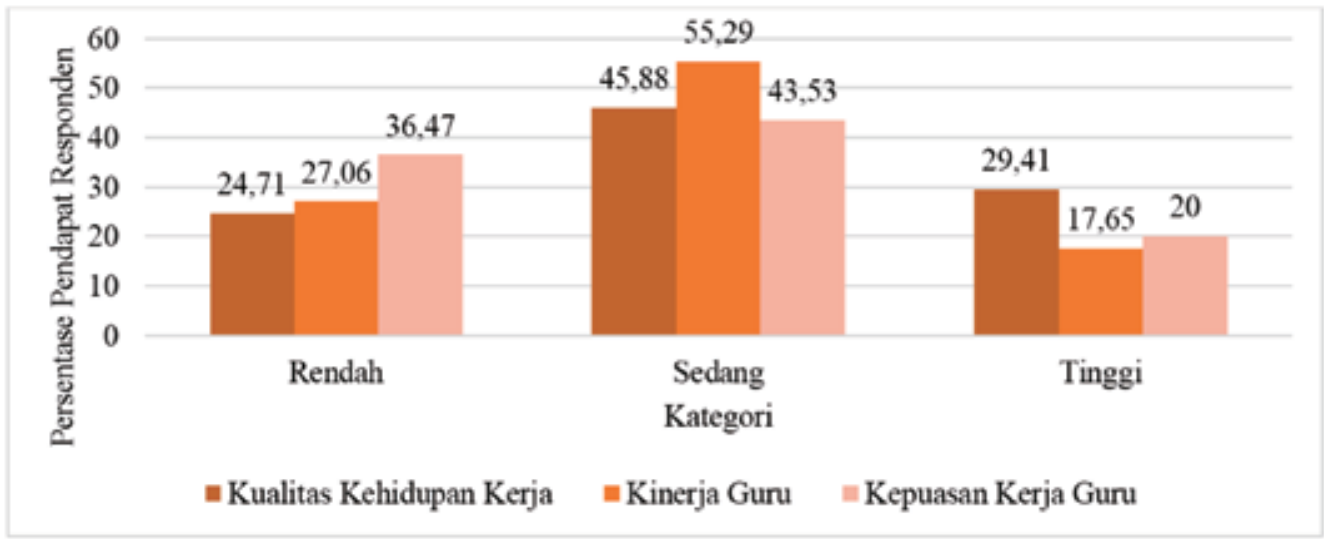

Gambar 1. Grafik Pendapat Responden Tentang Variabel Penelitian 
Berdasarkan Gambar 1 di atas dapat dalam kategori rendah, 43,53\% dalam kategori disimpulkan bahwa pendapat responden sedang, dan 20,00\% dalam kategori tinggi.

tentang kualitas kehidupan kerja di SMAN Sebelum analisis data, terlebih dahulu Kota Mataram sebesar 27,41\% dalam kategori dilakukan uji normalitas, homogenitas, rendah, 45,88\% dalam kategori sedang, dan $29,41 \%$ dalam kategori tinggi. Pendapat responden tentang kinerja guru SMAN di Kota Mataram sebesar 27,06\% dalam kategori rendah, 55,29\% dalam kategori sedang, dan $17,65 \%$ dalam kategori tinggi. Pendapat responden tentang kepuasan kerja guru SMAN di Kota Mataram sebesar 36,47\% multikolinieritas, dan autokorelasi. Dari hasil uji yang dilakukan menunjukkan bahwa semua data telah memenuhi syarat untuk dilakukan uji hipotesis dengan menggunakan uji statistik. Hasil uji statistik untuk melihat pengaruh masing-masing variabel bebas terhadap bariabel terikat yang dapat dirangkum dalam Tabel 1 sebagai berikut.

\section{Tabel 1 Pengaruh Variabel masing-masing variabel X terhadap Variabel Y}

\begin{tabular}{|c|c|c|c|c|c|}
\hline \multirow[b]{2}{*}{ Variabel } & \multicolumn{2}{|c|}{ Koefisien Regresi } & \multirow[b]{2}{*}{$t_{\text {hitung }}$} & \multirow[b]{2}{*}{ Sig. } & \multirow[b]{2}{*}{$\mathrm{R}^{2}$} \\
\hline & Konstanta & $\begin{array}{l}\text { Koefisien Regresi } \\
\text { (b) }\end{array}$ & & & \\
\hline Kualitas Kehidupan Kerja & 60,003 & 0,249 & 2,904 & 0,005 & 0,092 \\
\hline Kinerja Guru & 57,575 & 0,287 & 2,955 & 0,004 & 0,095 \\
\hline
\end{tabular}

Berdasarkan Tabel 1 di atas untuk kualitas kehidupan kerja diperoleh nilai thitung sebesar 2,904 lebih besar daripada nilai ttabel sebesar 1,989 (thitung $>$ ttabel) dan nilai signifikan diperoleh sebesar 0,005 lebih kecil daripada 0,05 (Sig. $<0,05)$, sehingga terdapat pengaruh yang signifikan kualitas kehidupan kerja terhadap kepuasan kerja guru SMA Negeri di Kota Mataram. Berdasarkan hasil analisis diperoleh koefisien regresi kualitas kehidupan kerja b sebesar 0,249 dan konstanta (intercept) a sebesar 57,575. Dengan demikian, pengaruh kualitas kehidupan kerja terhadap kepuasan kerja guru SMA Negeri di Kota Mataram ditunjukkan oleh persamaan $\hat{\mathrm{Y}}=60,003+0,249 \quad \mathrm{X}_{-} 1$. Artinya bahwa perubahan satu unit persepsi pada peubah kinerja guru diikuti oleh perubahan kepuasan kerja guru SMA Negeri di Kota Mataram sebesar 0,287 unit dengan intercept sebesar 57,575. Kualitas kehidupan kerja berpengaruh signifikan sebesar 9,2\% terhadap kepuasan kerja guru SMA Negeri di Kota Mataram.

Adanya pengaruh kualitas kehidupan kerja terhadap kepuasan kerja guru SMA Negeri di Kota Mataram disebabkan karena sebagian besar guru SMA Negeri di Kota Mataram berpendapat bahwa kualitas kerja di SMA Negeri Kota Mataram sudah cukup baik. hal ini dibuktikan dari pendapat responden berdasarkan angket kualitas kehidupan kerja yang menunjukkan 45,88\% menyatakan sedang (cukup) dan 39,41\% menyatakan tinggi (baik). Hasil penelitian ini didukung oleh hasil penelitian yang dilakukan sebelumnya yaitu penelitian yang dilakukan oleh Soltanzadeh et al. (2012), Zakerian et al. (2012), Shahbazi et al. (2011), Heidarie et al. (2010), Goudarznand-Chegini et al. (2010), Saedi et al. (2010), Mirkamali and Narenji (2008), HongLu (2007), Hua (2006), Conklin (2008), and Adhikari (2010) yang menyatakan 
bahwa terdapat pengaruh signifikan kualitas kehidupan kerja terhadap kepuasan kerja.

Pada kinerja guru diperoleh thitung sebesar 2,955 lebih besar daripada nilai ttabel sebesar 1,989 (thitung $>$ ttabel) dan nilai signifikan diperoleh sebesar 0,005 lebih kecil daripada 0,05 (Sig. < 0,05), sehingga dapat disimpulkan bahwa terdapat pengaruh yang signifikan kinerja guru terhadap kepuasan kerja guru SMA Negeri di Kota Mataram. Berdasarkan hasil analisis diperoleh koefisien regresi $b$ sebesar 0,287 dan konstanta (intercept) a sebesar 57,575. Dengan demikian, pengaruh kinerja guru terhadap kepuasan kerja guru SMA Negeri di Kota Mataram ditunjukkan oleh persamaan $\hat{Y}=57,575+0,287$ X_2. Artinya bahwa perubahan satu unit persepsi pada peubah kinerja guru diikuti oleh perubahan kepuasan kerja guru SMA Negeri di Kota Mataram sebesar 0,287 unit dengan intercept sebesar 57,575. Kinerja guru berpengaruh signifikan sebesar 9,5\% terhadap kepuasan kerja guru SMA Negeri di Kota Mataram.

Adanya pengaruh kinerja guru terhadap kepuasan kerja guru SMA Negeri di Kota Mataram ditunjukkan dari pendapat responden tentang kinerja guru SMA Negeri di Kota Mataram yang menyatakan bahwa 55,29\% kinerja guru termasuk dalam kategori sedang dan 17,65\% kinerja guru dalam kategori tinggi. Sikap guru terhadap pekerjaannya akan menentukan perasaan puas atau tidak seorang guru di sekolah. Amstrong (2006:264) mengemukakan bahwa, kepuasan kerja (job satisfaction) mengacu pada sikap dan perasaan yang dimiliki seseorang mengenai pekerjaan. Rivai dan Mulyadi (dalam Kusumayani, 2013:3) menjelaskan bahwa, kepuasan kerja (job Satisfaction) merupakan sikap umum individu terhadap pekerjaannya. Seseorang dengan tingkat kepuasan kerja tinggi menunjukkan sikap yang positif terhadap pekerjaannya itu, seseorang yang tidak puas dengan pekerjaanya menunjukkan sikap negatif terhadap pekerjaan itu. Dengan demikian, meningkatkan kinerja guru SMA negeri di Kota Mataram merupakan hal yang sangat penting untuk dilakukan, karena dengan kinerja guru yang baik, kepuasan kerja guru juga akan meningkat sehingga guru akan merasa betah dalam bekerja dan menikmati pekerjaannya.

Pengaruh kualitas kehidupan kerja dan kinerja guru secara bersama-sama terhadap kepuasan kerja guru SMA Negeri di Kota Mataram di analisis menggunakan regresi ganda. Hasil analisis ditunjukkan pada Tabel sebagai berikut.

Tabel 2. Pengaruh Variabel $\mathrm{X}_{1}$ dan $\mathrm{X}_{2}$ secara bersama-sama terhadap Variabel $\mathrm{Y}$

\begin{tabular}{lcccc}
\hline \multicolumn{1}{c}{ Model } & Koefisien Regresi & Fhitung & Sig. & $\mathrm{R}^{2}$ \\
\hline Konstan $(a)$ & 39,808 & 8,802 & 0,000 & 0,177 \\
\hline Kualitas Kehidupan Kerja (b1) & 0,235 & & & \\
\hline Kinerja Guru (b2) & 0,271 & & & \\
\hline
\end{tabular}

Berdasarkan Tabel 2 di atas, diperoleh nilai Fhitung sebesar 8,802 lebih besar daripada Ftabel sebesar 3.110 dan diperoleh nilai signifikan diperoleh sebesar 0,000 lebih kecil daripada 0,05 (Sig. <0,05). Dengan demikian, dapat disimpulkan bahwa terdapat pengaruh yang signifikan kualitas kehidupan kerja dan kinerja guru secara bersama-sama 
terhadap kepuasan kerja guru SMA Negeri di Kota Mataram. Kualitas kehidupan kerja dan kinerja guru ecara bersama-sama berpengaruh signifikan sebesar $17,7 \%$ terhadap kepuasan kerja guru SMA Negeri di Kota Mataram.

Berdasarkan hasil analisis, diperoleh koefisien arah regresi b1 sebesar 0,235, arah regseri b2 sebesar 0,271, dan konstanta (intercept) a sebesar 39,808. Dengan demikian, pengaruh kualitas kehidupan kerja dan kinerja guru secara bersama-sama terhadap kepuasan kerja guru ditunjukkan oleh persamaan $\hat{Y}=39,808+0,235 X \_1+0,271$ X_2. Artinya bahwa: 1) Perubahan satu unit persepsi pada kualitas kehidupan kerja (X1) dan faktor kinerja guru dianggap konstan, akan diikuti oleh perubahan kepuasan kerja guru (Y) sebesar 0,235 unit pada intercept sebesar 39,808. 2) Perubahan satu unit pada kinerja guru (X2) dan faktor kualitas kehidupan kerja dianggap konstan, akan diikuti oleh perubahan kepuasan kerja guru (Y) sebesar 0,271 pada intercept sebesar 39,808.

Kepuasan kerja guru lebih besar dipengaruhi oleh kineja guru dibandingkan dengan kualitas kehidupan kerja. Hal ini membuktikan bahwa, kepuasan kerja guru lebih cendrung meningkat apabila kinerja yang dimiliki guru sangat baik. Amir (2014:102) menyatakan bahwa kepuasan kerja guru ditandai dengan munculnya rasa puas dan terselesaikannya tugas-tugas yang menjadi tanggung jawab guru tersebut secara tepat waktu, disamping itu munculnya dedikasi, kegairahan, kerajinan, ketekunan, inisiatif, dan kreativitas kerja yang tinggi dalam bekerja. Hasil penelitian yang dilakukan oleh Perdani (2010) bahwa kepuasan kerja guru menurut faktor prestasi sebesar $45 \%$ meyatakan cukup puas; kepuasan kerja menurut faktor pengakuan sebesar $46,7 \%$ menyatakan cukup puas; kepuasan kerja menurut faktor pekerjaan itu sendiri sebesar 35,7\% menyatakan puas. Sehingga secara umum hasil penelitian yang dilakukan oleh Perdani (2010) menunjukkan bahwa kepuasan kerja guru SMA Negeri 46 Jakarta berada pada katogori puas dengan indikator prestasi, pengakuan, dan pekerjaan itu sendiri. Hasil penelitian yang dilakukan Perdani (2010) mendukung penelitian ini dengan yaitu kepuasan kerja guru SMA Negeri di Kota Mataram lebih cendrung dapat ditingkatkan melalui peningkatan kinerja/ prestasi kerja guru.

Walaupun kepuasan kerja guru SMA Negeri di Kota Mataram ini lebih besar dipengaruhi oleh faktor kinerja guru dari pada faktor kualitas kehidupan kerja, namun pada intinya kedua faktor tersebut dapat meningkatkan kepuasan kerja guru SMA Negeri di Kota Mataram secara bersama-sama, sehingga kualitas kehidupan kerja dan kinerja guru merupakan dua faktor penting yang yang harus diperhatikan dalam meningkatkan kepuasan kerja guru. Hal ini dibuktikan dengan sumbangsih kualitas kehidupan kerja dan kinerja guru dalam meningkatkan kepuasan kerja guru SMA Negeri di Kota Mataram sebesar 17\%. Persentase tersebut menunjukkan bahwa walaupun banyak faktor yang mempengaruhi kepuasan kerja guru, namun kualitas kehidupan kerja dan kinerja guru mempunyai peran dalam meningkatkan kepuasan keja guru SMA Negeri di Kota Mataram.

\section{KESIMPULAN}

Berdasarkan hasil yang diperoleh dalam penelitian ini maka dapat ditarik kesimpulan sebagai berikut:

Terdapat pengaruh signifikan kualitas kehidupan kerja terhadap kepuasan kerja guru 
SMA Negeri di Kota Mataram. Semakin baik kualitas kehidupan kerja, maka kepuasan kerja guru SMA Negeri di Kota Mataram akan semakin baik.

Terdapat pengaruh signifikan kinerja guru terhadap kepuasan kerja guru SMA Negeri di Kota Mataram. Semakin baik kinerja guru, maka kepuasan kerja guru SMA Negeri di Kota Mataram juga akan semakin baik.

Terdapat pengaruh signifikan kualitas kehidupan kerja dan kinerja guru secara bersama-sama terhadap kepuasan kerja guru SMA Negeri di Kota Mataram. Semakin baik kualitas kehidupan kerja dan kinerja guru secara bersama-sama, maka akan meningkatkan kepuasan kerja guru SMA Negeri di Kota Mataram

\section{DAFTAR PUSTAKA}

Adhikari, D. R., \& Gautam, D.K.2010. Labor Legislations for Improving Quality of Work Life in Nepal. International Journal of Law and Management. (52). 1. pp. 40-53.

Amir, A.

Chairil. Marzuki, Zahari Hasim. 2014.

Pengaruh Kompetensi Guru terhadap Kepuasan Kerja Guru SMA Negeri Pariaman. Jurnal Kebijakan dan Pengembangan Pendidikan. (2).2. pp. 101-106.

Amstrong, $\mathrm{M}$.

(2006). A Handbook of Human Resources Management Practice (10th ed.). London: Kogan Page.

Arikunto, S.

2003. Prosedur Penelitian Suatu Pendekatan Praktek. Jakarta: Rineka Cipta.

Botutihe, S. N.

2010. Sumbangan Keadilan Organisasi,
Iklim Organisasi, dan Kepuasan Kerja terhadap Quality of Work Life (Studi Kasus Pada Karyawan Televisi Republik Indonesia. Jurnal Inovasi, (7).4. pp. 240253

Cascio, W. F.

2006. Managing Human Resources. Colorado: Mc Graw -Hill.

Conklin, M. H.

2008. An Examination of Pharmacy Faculty Quality of Work Life: Work Satisfaction, Turnover Intentions, and Self-Efficacy (MSc Dissertation). Duquesne University.

Elfitrie, R.

2006. Kepuasan Kerja Pegawai di Direktorat Pengawasan Bank 3 - Bank Indonesia. Tesis. Jakarta: Universitas Indonesia

Goudarznand-Chegini, M., \&

Mirdoozandeh, G. 2012. Relationship between quality of work-life and job satisfaction of the employees in public hospitals in Rasht. Zahedan J Res Med Sci (ZJRMS). (14).1. pp. 108-111.

Heidarie, A.

Askary, P. Saedi, S. \& Gorjian, B. 2012. Relationship between Quality of Work Life Organizational Health and Commitment with Job Satisfaction. Life Science Journal. (9).1. pp. 2300-2306. HongLu, H.,

While, A. E., \& Barriball, K. 2007. Job satisfaction and its related factors: A questionnaire survey of hospital nurses in Mainland China. International journal of nursing studies, (44).1. pp. 574-588. Hua, J.

2006. A study of relationship on bureau of investigation officials, quality of work life, work pressure and job satisfaction 
(Master's thesis, Public Affairs Management).

Jofreh, M.,

Dashgarzadeh, K., \& Khoshbeen, F. 2012. The Relationship between Quality of Work Life with Staff Performance of Iranian Gas Engineering and Development Company. Research Journal of Applied Sciences, Engineering and Technology (4). 15. pp. 2507-2514

Kasraie, S.,

Parsa, Sheler, Hassani Mohammad, Zadeh, A. G. 2014. The Relationship between Quality of Work Life, Job Stress, Job Satisfaction, and Citizenship Behavior in Oshnaviyeh Hospital's Staff. Patient Safety \& Quality Inprovement Journal. (2).2. pp. 77-81.

Kermansaravi, F.

Navildian Ali. Rigi S. Navabi \& Yaghoubinia, Fariba. 2015. The Relationship between Quality of Work Life and Job Satisfaction of Faculty Menbers in Zahedan University of Medical Sciences. Global Journal of Health Science. (7).2. pp. 228-234.

Kusumayani, A.,

Nyoman Natajaya, Atmadja Bawa. 2013.

Kontribusi Perilaku Kepemimpinan Kepala Sekolah, Kepuasan Kerja Guru, Dan Komitmen Kerja Guru Terhadap Kinerja Guru SMA Negeri Di Kota Amlapura. e-Journal Program Pascasarjana Universitas Pendidikan Ganesha Program Studi Administrasi Pendidikan. (4).1. pp. 1-8.

Mangkunegara.

2010. Manajemen Sumber Daya Manusia Perusahaan.Bandung: PT Remaja Rosdakarya.

Marsana. 2010. Pengaruh Kompetensi dan Motivasi Kerja terhadap Kepuasan Kerja Serta Implikasinya Pada Kinerja Guru (Studi Kasus pada SMA Negeri se Sub Rayon 1 Semarang). Jurnal Ekonomi Manajemen Akuntasi. Vol. (17).18. pp. $1-15$.

Mirkamali, S.

Mohammad \& Thani, F. Narenji. 2011. A Study on Quality of Work Life (QWL) among Faculty Members of University of Tehran (UT) and Sharif University of Technology (SUT). Procidia-Sosial and Bahavioral Sciences. (29).1. pp. 181192.

Perdani, P. Putri.

2010. Analisis Kepuasan Kerja Guru (Suatu Studi di SMA Negeri 46 Jakarta). Tesis. Jakarta: Universitas Indonesia Rivai, V.,

Ella Jauvani Sagala.

(2009). Manajemen Sumber Daya Manusia untuk Perusahaan Dari Teori ke Praktik (edisi kedua). Jakarta: Rajawali Pers.

Robbins, S. P.

(2001). Organizational Behavior (9th ed.). New Jersey: Prentice Hall.

Rokhman, W.

2012. Pengaruh Quality of Work Life Terhadap Kepuasan Kerja, Komitmen Organisasi, Turnover Intention dan Stes Kerja: Studi Pada BMT Di Kabupaten Kudus. Prociddings of Compference in Business, Accounting and Management (CBM-FE). (1).1.

Saedi, S.,

Khalatbari, J., \& Murray Najafabadi, N. 2010. Relationship between quality of work life and organizational health with job satisfaction. Journal of Modern Industrial/Organization Psycholo, (1).4. 
pp. 55-64.

Shahbazi, B.,

Vaezi M., \& Sanai poor, H. 2009.

Explain the relationship between the quality of working life and performance management departments of universities. Journal of Public Administration, (3).1, pp. 69-84.

Singh.

2013. Relationship between Teaching Competence and Job Satisfaction: A Study among Teacher Educators Working in Self-Finacing Colleges in Uttar Pradesh, India. Reseach Paper Education, (17).3. pp. 182-184.

Soltanzadeh, V.,

Ghalvandy H., \& Fatahy M.

(2012) A Study of the Relationship between the Quality of Work Life and Job Satisfaction among the Faculty Members of Shiraz University. Journal of Human Resource Management Researches, (4).2. pp. 125-149.

Sudirman.

2015. Hasil UKG NTB 2015 Mengecewakan. [Online]. Halaman 1. Tersedia: http://www.radarlombok.co.id/ hasil-ukg-ntb-2015-mengecewakan.html . (16 Februari 2016).

Sugiyono.

2008. Metode Penelitian Pendidikan, Pendekatan Kuantitatif, Kualitatif, dan R dan D. Bandung: Alfa Beta.

2011. Statistika untuk penelitian. Bandung: Alfa Beta.

Sukardi.

2008. Evaluasi Pendidikan Prinsip dan Operasionalnya. Jakarta Timur. PT. Bumi Aksara.

Supardi.
2014. Kinerja Guru. Jakarta. Raja Grapindo Persada.

Susilowati.

2009. Pengaruh Kepemimpinan, Lingkungan Kerja, Pengembangan Karir, Komunikasi Dan Insentif Terhadap Kepuasan Kerja Guru Sma Negeri I Cawas Kabupaten Klaten. Exellent. (2).1. pp. 1-23.

Tasir, Z.

2012. Relationship between Teacher's ICT Competency, Comfidance Level, and Satisfaction toward ICT Trainning Programmes: A

Case Study among Postgraduate Students. Turkish Online Journal of Educational Technology. (11).1. pp. 138144.

Yuliejantiningsih, Y.

2012. Hubungan Iklim Sekolah, Beban Tugas, Motivasi Berprestasi, dan Kepuasan Kerja Guru dengan Kinerja Guru SD. JMP. (1). 3. pp. 239-256.

Zakerian, S. A.,

Teymuri G. H., Ahmadnezhad, I., Abbassinia, M., Rahmani, A., \& Asghari, M. 2014. Investigating the Dimensions of Quality of Work Life and Its Relation to Job Satisfaction in an Automotive Industry. Journal of Ergonomics, (1).3. pp. $36-45$. 